\title{
A NEW SYSTEM OF GENERALIZED NONLINEAR MIXED VARIATIONAL INEQUALITIES
}

\author{
JIAN-WEN PENG AND HONG-LIN LUO
}

\begin{abstract}
In this paper, we introduce and study a new system of generalized nonlinear mixed variational inequalities which contains some classes of variational inequalities and systems of variational inequalities in the literature as special cases. We prove the existence and uniqueness of solution and the convergence of some new $n$-step iterative algorithms with mixed errors for this system of generalized nonlinear mixed variational inequalities and its special cases. The results in this paper unify, extend and improve some known results in the literature.
\end{abstract}

Mathematics subject classification (2000): 49J40, 47H10.

Key words and phrases: Existence, convergence, a system of generalized nonlinear mixed variational inequalities, $n$-step iterative sequence with mixed errors.

\section{REFERENCES}

[1] E. ALLEVI, A. GNUDI AND I. V. KonNov, Generalized vector variational inequalies over product sets, Nonlinear Analysis 47 (2001), 573-582.

[2] Q. H. ANSARI, A note on generalized vector variational-like inequalities, Optimization, 1997, 41:197205.

[3] Q. H. ANSARI, Extended generalized vector variational-like inequalities for nonmonotone multivalued maps, Ann. Sci. Math., 1997, 21 (1):1-11.

[4] Q. H. ANSARI AND J. C. YAO, A fixed point theorem and its applications to a system of variational inequalities, Bull. Austral. Math. Soc. 59 (1999), 433-442.

[5] Q. H. ANSARI, S. SCHAIBLE AND J. C. YAO, Systems of Vector Equilibrium problems and its applications, J. Optim. Theory and Appl. 107 (2000), 547-557.

[6] M. BIANCHI, Pseudo P-monotone operators and variational inequalities, Report 6, Istituto di econometria e Matematica per le decisioni economiche, (Universita Cattolica del Sacro Cuore, Milan, Italy, 1993).

[7] H. BREZIS, Operateurs Maximaux Monotone et Semigroups de Contractions dans les Espaces de Hilbert, North-Holland, Amsterdam (1973).

[8] G. Y. CHEN, Existence of solutions for a vector variational inequality: an existension of the HartmannStampacchia theorem, J. Optim. Theory and Appl., 1992, 74 (3):445-456.

[9] G. Y. CHEN AND G. M. CHENG, Vector variational inequalities and vector optimization, In Lecture Notes in Economics and Mathematical Systems, 1987, 285:408-456.

[10] G. Y. ChEN AND B. D. CRAVEN, Approximate dual and approximate vetor variational inequality for multiobjective optimization, J. Austral. Math. soc., Ser. A 1989, 47:418-423.

[11] G. Y. CHEN AND B. D. CRAVEN, A vector variational inequality and optimization over an efficient set, Zeitschrift fur operations Research 1990, 3:1-12.

[12] G. Y. CHEN AND X. Q. YANG, Vector complementarity problems and its equivalences with the weak minimal element in ordered spaces, J. Math. Anal. Appl., 1990, 53:136-158.

[13] Y. J. CHO, Y. P. FANG AND N. J. HUANG, Algorithms for systems of nonlinear variational variational inequalities, J. Korean Math. Soc. 41 (2004), 489-499.

[14] G. COHEN AND F. CHAPLAIS, Nested monotony for variational inequalities over a product of spaces and convergence of iterative algorithms, J. Optim. Theory and Appl. 59 (1988), 360-390.

[15] A. DANIILIDI AND N. HADJISAVVAS, Existence theorems for vector variational inequalities, Bull. Austral. Math. Soc., 1996, 54, 473-481. 
[16] X. P. DING, The generalized vector quasi-variational-like inequalities, Computers and Mathematics with Applications, 1999, 37:57-67.

[17] X. P. DING, Existence and algorithms of solutions for nonlinear mixed variational-like inequalities in Banach spaces, J. Comput. Appl. Math. 157 (2003), 419-434.

[18] X. P. DING AND E. TARAFDAR, Generalized vector variational-like inequalities without monotonicity, pp. 113-123. Vector variational inequalities and vector equilibrium: mathematical theoreies, In: Giannessi, F. (Eds.), Kluwer Academic Publishers, 2000.

[19] X. P. Ding AND E. TARAFDAR, Generalized vector variational-like inequalities with $C_{x}-\eta$ pseudomonotone set-valued mappings, pp. 125-140. Vector variational inequalities and vector equilibrium: mathematical theoreies, In: Giannessi, F. (Eds.), Kluwer Academic Publishers, 2000.

[20] A. S. EMAN AND C. B. STEPHEN, An iterative method for generalized set-valued nonlinear mixed quasi-variational inequalities, J. Compul. Appl. Math. 170 (2004), 423-432.

[21] F. GIANNESSI, Theorems alternative, Quadratic programs, and complementarity problems, In variational inequalities and complementarity problems, (Edited by R. W. Cottle, F. Giannessi, and J. L. Lions), pp. 151-186, John Wiley and Sons, New York, 1980.

[22] P. T. HARKER, J. S. PANG, Finite-dimensional variational inequality and nonlinear complementarity problems: a survey of theory, algorithms and applications, Math. Prog. 48 (1990), 161-220.

[23] G. Kassay, J. Kolumbán, System of multi-valued variational inequalities, Publ. Math. Debrecen, 54 (1999), 267-279.

[24] G. KASSAY, J. KOlUmBÁn AND Z. PÁLES, Factorization of Minty and Stampacchia variational inequality system, European J. Oper. Res., 143 (2002), 377-389.

[25] J. K. KIM AND D. S. KIM, A new system of generalized nonlinear mixed variational inequalities in Hilbert spaces, J. Convex Anal. 11(1) (2004), 235-243.

[26] I. V. KonNOV AND J. C. YAO, On the generalized vector variational inequality problem, J. Math. anal. Appl., 1997, 206:42-58.

[27] G. M. LEE, D. S. KIM AND S. J. CHO, Generalized vector variational inequality and fuzzy extension, Appl. Math. Lett., 1993, 6(6):47-51.

[28] G. M. LEE, B. S. LeE AND S. S. Chang, On vector quasivariational inequalities, J. Math. Anal. Appl., 1996, 203, 626-639.

[29] J. L. LI, On the existence of solutions of variational-inequalities in Banach spaces, J. Math. Anal. Appl. 295 (2004), 115-128.

[30] K. L. LIN, D. P. DING AND J. C. YAO, Generalized vector variational inequalities, J. Optim. Theory and Appl., 1997, 92(1):117-125.

[31] G. M. LEE, D. S. KIM AND B. S. LEE, Generalized vector variational inequality, Appl. Math. Lett., 1996, 9(1):39-42.

[32] L. S. LIU, Ishikawa and Mann, Iterative process with error for nonlinear strongly accretive mappings in Banach spaces, J. Math. Appl. Anal. (1995) 114-125.

[33] Q. LuO, Generalized vector variational-like inequalities, pp. 363-369. Vector variational inequalities and vector equilibrium: mathematical theoreies, In: Giannessi, F. (Eds.), Kluwer Academic Publishers, 2000.

[34] P. MARCOTTE AND D. L. ZHU, Weak sharp solutions and the finite convergence of algorithms for solving variational inequalities, SIAM J. Optim. 9 (1999), 179-189.

[35] M. A. NOOR, Modified resolvent splitting algorithms for general mixed variational inequalities, J. Comput. Appl. Math. 135 (2001), 111-124.

[36] M. A. NOOR, K. I. NOOR AND T. M. RASSIAS, set-valued resolvent equations and mixed variational inequalities, J. Math. Anal. Appl., 220 (1998) 741-759.

[37] J. S. PANG, Asymmetric variational inequality problems over product sets: Applications and iterative methods, Mathematical Programming 31 (1985), 206-219.

[38] J. W. PenG, System of generalized set-valued quasi-variational-like inequalities, Bull. Austral. Math. Soc. 68 (2003), 501-515.

[39] J. W. PENG AND X. M. YANG, On existence of a solution for the system of generalized vector quasiequilibrium problems with upper semicontinuous set-valued maps, Internat. J. Math. Math. Sci., 15 (2005):2409-2420.

[40] A. H. Siddiei, A. H. Ansari, A. KhaliQ, On vector variational inequality, J. Optim. Theory Appl. 1995, 84:171-180.

[41] R. U. VERMA, Projection methods, algorithms and a new system of nonlinear variational inequalities, Computers Math. Applic. 41 (2001), 1025-1031.

[42] R. U. VERMA, General convergence analysis for two-step projection methods and application to variational problems, Appl. Math. Lett. 18 (2005), 1286-1292. 
[43] R. U. VERMA, On a new system of nonlinear variational inequalities and associated iterative algorithms, Math. Sci. Res. Hot-Line 3(8) (1999), 65-68.

[44] R. U. VERMA, Iterative algorithms and a new system of nonlinear quasivariational inequalities, Adv. Nonlinear Var. Inequal. 4(1) (2001), 117-124.

[45] R. U. VeRMA, Generalized system for relaxed cocoercive variational inequalities and problems and projection methods, J. Optim. Theory and Appl. 121(1) (2004), 203-210.

[46] N. H. XIU AND J. Z. ZHANG, Some recent advances in projection-type methods for variational inequalities, J. Comput. Appl. Math. 152 (2003), 559-585.

[47] X. Q. YANG, Vector variational inequality and duality, Nonlinear Analysis, Theory, Methods \& Applications, 1993, 21(11):869-877.

[48] X. Q. YANG, Generalized convex functions and vector variational inequality, J. Optim. Theory Appl., 1993, 79:563-580.

[49] X. Q. YANG AND J. C. YAO, Gap functions and existence of solutions to set-valued vector variational inequalies, J. Optim. Theory and Appl., 2002, 115(2) P:407-417.

[50] G. X. Z. YUAN, KKM Theory and Applications, Marcel Dekker, New York (1999).

[51] S. J. YU AND J. C. YAO, On vector variational inequality, J. Optim. Theory Appl., 1996, 89:749-769.

[52] D. L. ZHU AND P. MARCOTTE, Co-coercivity and its role in the convergence of iterative schemes for solving variational inequality problems, SIAM J. Optim. 6 (1996), 714-726. 